\title{
Involvement of the heparan sulphate-binding proteins of Helicobacter pylori in its adherence to HeLa S3 and Kato III cell lines
}

\author{
MARIA A. GUZMAN-MURILLO, EDUARDO RUIZ-BUSTOS, BOW HO* and FELIPE ASCENCIO† \\ Center for Biological Research, Marine Pathology Unit, La Paz, BCS 23000, Mexico and*Department of \\ Microbiology, National University of Singapore, Singapore 117597
}

\begin{abstract}
To determine whether Helicobacter pylori heparan sulphate-binding proteins (HSBPs) are involved in the adherence of $H$. pylori to HeLa and Kato III cells, monolayers were pre-incubated with various preparations and concentrations of $\mathrm{H}$. pylori HSBPs at $37^{\circ} \mathrm{C}$, washed and then challenged with bacteria. HSBPs did not prevent but enhanced $H$. pylori adherence. However, challenging cultured cells with $H$. pylori previously incubated with rabbit anti-HSBP IgG resulted in significant inhibition of bacterial adherence. These data demonstrate that the extracellular HSBP plays an important role in promoting $H$. pylori attachment to Kato III and HeLa S3 cells, that adhesion of $H$. pylori to Kato III and HeLa S3 cells is promoted by the presence of the 71.5-kDa extracellular HSBP and that rabbit polyclonal antibodies against this HSBP can inhibit adhesion of $\boldsymbol{H}$. pylori to the cultured cell lines and detach cell-bound $\boldsymbol{H}$. pylori.
\end{abstract}

\section{Introduction}

Epidemiological studies have provided evidence of a correlation between the presence of Helicobacter pylori in the gastric antrum and duodenal ulcers $[1,2]$. Futhermore, epidemiological data sustain the hypothesis of an association between infection with $H$. pylori and the development of various gastric cancers [3]. Adhesion of $H$. pylori to human gastric mucosa is an important step in $H$. pylori colonisation. Thus, in developing strategies against $H$. pylori infection, it is important to analyse the adhesion mechanisms of this pathogen [4]. Cell adhesion in conjunction with the production of surface urease, lipase and toxic proteins may induce rapid destruction of epithelial cells, exposing subepithelial tissue and extracellular matrix. Bacteria can attach to the basement membrane by high affinity binding via collagen IV and laminin [5]. Laminin and collagen IV help to bind epithelial cells to the basal lamina and fibronectin helps to bind the matrix macromolecules and connective tissue on the

Received 8 May 2000; revised version received 22 Aug. 2000; accepted 11 Sept. 2000.

†Corresponding author: Dr F. Ascencio (e-mail: micv4@ nus.edu.sg). Present address: Department of Microbiology, National University of Singapore, MD4/A, Science Drive 2, Singapore 117597. opposite side [6]. Several researchers have proposed that $H$. pylori recognises other cell receptors, such as those glycoconjugates exposed on HeLa, HEp-2, Vero and Kato III cells lines [7-10], or sialic acid-rich glycoproteins [11]. H. pylori also binds sulphated glycolipids [12], sulphomucins [13] and sulphated glycosaminoglycans such as those exposed on Kato III and Hu Tu-80 cells [14-16]. The high affinity of $H$. pylori for these molecules suggests that cell surface and extracelular matrix heparan sulphate are likely to be targets for $H$. pylori at an early stage of colonisation of the gastric mucosa.

Binding of $H$. pylori to all these host molecules may be also a strategy of the bacteria to prevent attack by phagocytes and immune reactions. Such phenomena may in part explain why $H$. pylori is a slow pathogen $[17,18]$ that can survive in the gastric mucosa for decades in patients with chronic type B gastritis. Chmiela et al. [19] demonstrated that $H$. pylori also used heparan sulphate-binding activity in its adhesion to murine peritoneal macrophages.

The aims of the present study were to investigate whether heparan sulphate-binding proteins (HSBPs) of H. pylori are involved in the adhesion of the bacteria to HeLa S3 and to Kato III cell lines, and whether bacterial adhesion can be blocked with polyclonal antibodies raised against a $71.5-\mathrm{kDa}$ extracellular HSBP from $H$. pylori. 


\section{Materials and methods}

\section{Bacteria and growth conditions}

H. pylori strain 25 was obtained from Professor $\mathrm{T}$. Wadström (Department of Medical Microbiology, University of Lund, Sweden). This strain was isolated from a patient with duodenal ulcer disease. Identification was based on Gram's staining, cell morphology and positive reactions for catalase, oxidase and urease activity, and then confirmed with the API ZYM kit (bioMérieux, France) [20]. Further analysis indicated that H. pylori strain 25 binds heparan sulphate [14] and heparin-dependent growth factors [21] and that it is $\mathrm{Ure}^{+}$and $\mathrm{Cag}^{+}$[22]. H. pylori strains associated with gastro-oesophagal reflux disease (GERD) and duodenal ulcers and cancer-associated strains were isolated at the Department of Microbiology of the National University of Singapore from gastric biopsy samples obtained at the National University Hospital, Singapore, and identified as described above. H. pylori strain 51932 $\left(\mathrm{CagA}^{-}-\mathrm{VacA}^{-}, \mathrm{Ure}^{+}\right.$, non-cytotoxic) was obtained from the American Type Culture Collection (Mannasas, VA, USA) and $H$. pylori strain 51110 (a Ure ${ }^{-}$mutant, $\mathrm{Cag}^{+}-\mathrm{VacA}^{+}$and cytotoxic strain, generated from the reference $H$. pylori strain 49503, also from ATCC) was from Professor B. J. Marshall (Department of Microbiology, University of Western Australia, Perth, Australia). The strains were cultured on GAB-Camp agar supplemented with lysed human blood $\left(80^{\circ} \mathrm{C}, 20 \mathrm{~min}\right)$ $8.5 \%$, inactivated horse serum $\left(56^{\circ} \mathrm{C}, 30 \mathrm{~min}\right) 10 \%$, cysteine hydrochloride $0.05 \%$, IsoVitaleX $0.35 \%$ and the following antibiotics: vancomycin $(6 \mu \mathrm{g} / \mathrm{ml})$, nalidixic acid $(20 \mu \mathrm{g} / \mathrm{ml})$ and ketoconazole $(3 \mu \mathrm{g} / \mathrm{ml})$, and incubated at $37^{\circ} \mathrm{C}$ for $2-3$ days in micro-aerobic conditions $\left(\mathrm{O}_{2} 5 \%, \mathrm{CO}_{2} 10 \%, \mathrm{~N}_{2} 85 \%\right)$ [23]. For the isolation of the extracellular HSBPs, H. pylori strain 25 was cultured at $37^{\circ} \mathrm{C}$ (in the same micro-aerobic conditions as above) in Brucella broth containing fetal calf serum $10 \%$ and supplemented with antibiotics. Stock cultures of $H$. pylori were stored at $-80^{\circ} \mathrm{C}$ in trypticase soy broth (TSB) containing glycerol $15 \%$.

For cell adhesion studies, H. pylori strains were grown on GAB-Camp agar as described above, harvested and washed twice in phosphate-buffered saline (PBS). Bacterial cell suspensions were adjusted to a density of $10^{9} \mathrm{cfu} / \mathrm{ml}$ and then labelled with n-biotin as described previously [24].

The mouse-adapted $H$. pylori strain 25 was generated by repeated in-vivo passage, cultured as described above, through oral administration of $10^{9}$ cells $/ \mathrm{ml}$ $(0.5 \mathrm{ml} / \mathrm{mouse})$ in BALB $/ \mathrm{c}$ mice [25]. After 10 days of such treatment, mice were killed by cervical vertebral dislocation under light anaesthesia; stomach and small intestine were excised and homogenised in PBS. Then, $250 \mu 1$ of this suspension were cultured on GAB-Camp agar supplemented with human blood $8.5 \%$ and horse serum $10 \%$ and the following antibiotics: vancomycin $(100 \mu \mathrm{g} / \mathrm{ml})$, amphotericin B
$(50 \mu \mathrm{g} / \mathrm{ml})$ and nalidixic acid $(10.7 \mu \mathrm{g} / \mathrm{ml})$. Plates were incubated for $48 \mathrm{~h}$ and $H$. pylori colonies were identified by morphology and confirmed by a positive rapid urease reaction. The $H$. pylori strain was passaged through mouse gut up to eight times before use in the experiments.

\section{HeLa S3 and Kato III cell lines}

HeLa S3 cells, (derived from a human epithelioid carcinoma) and Kato III cells (a gastric adenocarcinoma cell line) were obtained from ATCC. The Kato III and HeLa S3 cells were grown in $75-\mathrm{cm}^{2}$ tissueculture flasks with RPMI-1640 medium containing gentamicin $40 \mu \mathrm{g} / \mathrm{ml}, 2 \mathrm{mM}$ L-glutamine, and supplemented with fetal calf serum (FCS) $15 \%$. The tissueculture flasks were incubated at $37^{\circ} \mathrm{C}$ (humidity $95 \%$ and $\mathrm{CO}_{2} 5 \%$ ). The cells were washed with PBS without $\mathrm{Mg}^{2+}$ and $\mathrm{Ca}^{2+}, \mathrm{pH} 7.2$, and then treated with trypsin $0.25 \%$ in Hanks's modified balanced salts solution for $5 \mathrm{~min}$ at $37^{\circ} \mathrm{C}$ to release the cells from the plastic surface. The trypsinised cells were resuspended in fresh medium and then seeded into new tissue-culture flasks. The cells were transferred approximately every 3 days for HeLa S3 and every 5 days for Kato III cells.

For cell adhesion studies, $100 \mu \mathrm{l}\left(4 \times 10^{7}\right.$ cells $\left./ \mathrm{ml}\right)$ of the Kato III and HeLa S3 cell suspensions in RPMI 1640 medium containing FCS $15 \%$ were seeded on to 96-well tissue-culture plates and incubated at $37^{\circ} \mathrm{C}$ until the formation of a semi-confluent cell monolayer.

\section{Isolation of H. pylori HSBPS}

Supernates from $H$. pylori strain 25 cultures, grown as described above, were precipitated with ammonium sulphate $60-80 \%$ saturation. The precipitated proteins were centrifuged $\left(18000 \mathrm{rpm}\right.$ for $30 \mathrm{~min}$ at $5^{\circ} \mathrm{C}$ ), resuspended in distilled water and then dialysed against $0.01 \mathrm{M}$ ammonium bicarbonate.

The protein fraction was subjected to a modified heparin affinity-chromatography procedure with a 5ml Heparin Hi-trap Column (Amersham Pharmacia Biotech, Uppsala, Sweden) equilibrated with $0.1 \mathrm{M}$ sodium acetate buffer, pH 5.0 [26]. Adsorbed proteins were eluted with an $\mathrm{NaCI}$ gradient $(0-2 \mathrm{M})$ over $30 \mathrm{~min}$ at the same flow rate $(1 \mathrm{ml} / \mathrm{min})$ and $1-\mathrm{ml}$ fractions were collected. Fractions were dialysed extensively against $0.01 \mathrm{M}$ ammonium bicarbonate and concentrated. SDS-PAGE and Western blot analysis of the chromatographed HSBP preparation, with horseradish peroxiodase labelled heparan sulphate as a probe, indicated the co-purification of three major protein bands of $71.5,66.2$ and $11.3 \mathrm{kDa}$ [26]. The first two proteins were sequenced at their amino-terminal region, and it was found that the $71.5-\mathrm{kDa}$ protein is a $H$. pylori protein that has not been described before [26], and this protein was further purified by SDS-PAGE to 
produce rabbit polyclonal antibodies and used in the blocking experiments described below.

\section{Horseradish peroxidase-labelling of HSBPs and heparan sulphate}

Chromatographically purified HSBPs (as described above) and heparan sulphate partially oxidised with $0.1 \mathrm{M} \mathrm{NalO}_{4}$ for $1 \mathrm{~h}$ at $22^{\circ} \mathrm{C}$ were conjugated with horseradish peroxidase as described previously [24]. Briefly, $0.2 \mathrm{ml}$ of $0.1 \mathrm{M} \mathrm{NalO}_{4}$ was mixed with $4 \mathrm{mg}$ of horseradish peroxidase. After incubation for $20 \mathrm{~min}$ at $22^{\circ} \mathrm{C}$, horseradish peroxidase was dialysed against $1 \mathrm{mM}$ sodium acetate buffer, $\mathrm{pH} 4.4$, at $4^{\circ} \mathrm{C}$ for $24 \mathrm{~h}$. This solution was then mixed with $1 \mathrm{mg}$ of heparan sulphate or HSBP in $0.01 \mathrm{M} \mathrm{Na}_{2} \mathrm{CO}_{3}$ buffer, $\mathrm{pH} 4.4$, and incubated at $22^{\circ} \mathrm{C}$ for $4 \mathrm{~h}$. The reaction was stopped by adding $100 \mu 1$ of $0.1 \mathrm{M} \mathrm{NaBH}_{4}$. Horseradish peroxidase labelled protein solutions were adjusted to $50 \% \mathrm{v} / \mathrm{v}$ with glycerol and stored at $-20^{\circ} \mathrm{C}$ until use.

\section{Binding of horseradish peroxidase-labelled HSBPs to H. pylori cells}

The binding assay was done in Eppendorf tubes as described previously for binding of horseradish peroxidase-labelled lactoferrin to $H$. pylori [27]. Briefly, $100 \mu \mathrm{l}$ of an $H$. pylori suspension $\left(10^{9}\right.$ cells) grown on GAB-Camp agar were mixed with $100 \mu \mathrm{l}$ of horseradish peroxidase-labelled HSBPs (stock solution diluted from 300 to $1 \mathrm{ng} / \mathrm{p} 100 \mu \mathrm{l}$ ) in $0.15 \mathrm{M}$ sodium phosphate buffer (PBS) $\mathrm{pH} 7.2$ at $37^{\circ} \mathrm{C}$ for $1 \mathrm{~h}$. After the addition of $2 \mathrm{ml}$ of ice-cold PBS containing Tween$20 \quad 0.05 \% \quad \mathrm{v} / \mathrm{v}$ (PBS-Tween), the mixtures were centrifuged $\left(4500 \mathrm{~g}, 15 \mathrm{~min}, 4^{\circ} \mathrm{C}\right)$ and the cell pellets were suspended in $100 \mu \mathrm{l}$ of horseradish peroxidase substrate solution (containing $o$-phenylenediamine-HCI $1 \mathrm{mg} / \mathrm{ml}$ in $50 \mathrm{mM}$ sodium citrate buffer, $\mathrm{pH} 5.0$ ), follow by incubation for $30 \mathrm{~min}$ at $22^{\circ} \mathrm{C}$. The reaction was stopped by adding $100 \mu 1$ of $2 \mathrm{M} \mathrm{H}_{2} \mathrm{SO}_{4}$ and the absorbance was measured at $495 \mathrm{~nm}$.

\section{Enzyme-linked, biotin-streptavidin bacterial adhesion assay}

Semi-confluent cell monolayers $\left(0.5-1.0 \times 10^{5}\right.$ cells/ well) grown on 96-well tissue-culture plates were washed three times in RPMI-1640 medium without antibiotics and incubated for $1 \mathrm{~h}$ at $25^{\circ} \mathrm{C}$ with a suspension of biotin-labelled H. pylori cells in RPMI1640 medium without antibiotics $\left(10^{9} \mathrm{cfu} / \mathrm{ml}\right)$. After incubation, plates were washed three times with PBSTween-20 to remove non-adhering bacteria. Then, $100 \mu \mathrm{l}$ of horseradish peroxidase-conjugated streptavidin (Boehringer Mannheim, GmbH, Germany; diluted 1 in 2000 in PBS) were added to each well and the plates were incubated for $90 \mathrm{~min}$ at $25^{\circ} \mathrm{C}$. After washing the plates three times with PBS-Tween, $100 \mu \mathrm{l}$ of $o$-phenylenediamine- $\mathrm{HCl}$ were added to each well, and the plates were incubated for further $20 \mathrm{~min}$ at $22^{\circ} \mathrm{C}$ in the dark. The reaction was stopped by the addition of $100 \mu \mathrm{l}$ of $2 \mathrm{M} \mathrm{H}_{2} \mathrm{SO}_{4}$ and colour development was measured at $495 \mathrm{~nm}$. Results of adhesion of biotin-labelled H. pylori to HeLa S3 and Kato III cell lines are expressed in optical density (OD) units.

Other adhesion studies were done with semi-confluent cell monolayers previously fixed with formaldehyde $0.5 \%$ in $0.1 \mathrm{M}$ phosphate buffer $(\mathrm{pH} 7.2)$ for $30 \mathrm{~min}$ at $37^{\circ} \mathrm{C}$. After washing five times with PBS-Tween, $200 \mu \mathrm{l}$ of bovine serum albumin (BSA) 3\% were added to each well. After incubation for $1 \mathrm{~h}$ at $37^{\circ} \mathrm{C}$, plates were washed three times with PBS-Tween and used for the enzyme-linked, biotin-streptavidin bacterial adhesion assay as described above.

Inhibition assays were done by incubating $H$. pylori suspensions $\left(100 \mu \mathrm{l}\right.$ containing $10^{9}$ cells) at $37^{\circ} \mathrm{C}$ for $1 \mathrm{~h}$ with $100 \mu \mathrm{l}$ of rabbit polyclonal antibodies raised against the $71.5-\mathrm{kDa} H$. pylori HSBP (previously diluted in PBS), and with non-immune rabbit serum. Pre-incubated bacterial suspensions were added to the HeLa S3 and Kato III cell monolayers and the enzymelinked, biotin-streptavidin bacterial adhesion assay was performed as described above.

Similarly, before the enzyme-linked, biotin-streptavidin bacterial adhesion assay, HeLa S3 and Kato III cell monolayers were pre-incubated for $1 \mathrm{~h}$ at $37^{\circ} \mathrm{C}$ with soluble HSBP adjusted to different concentrations (from $1 \mathrm{mg}$ to $1 \mu \mathrm{g} / \mathrm{ml}$ ) in PBS.

\section{Glycosidase treatment}

Formaldehyde-fixed cell monolayers were treated with several glycosidases. Bacteroides fragilis keratanase (endo- $\beta$-galactosidase) $(6 \mathrm{mU} / \mathrm{ml})$ digestion was done at $37^{\circ} \mathrm{C}$ for $24 \mathrm{~h}$ in $0.05 \mathrm{M}$ sodium acetate buffer (pH 5.8) containing BSA $0.2 \mathrm{mg} / \mathrm{ml}$. Escherichia coli $\beta$-galactosidase $(1 \mathrm{U} / \mathrm{ml})$ digestion was done in $0.1 \mathrm{M}$ sodium citrate buffer $(\mathrm{pH} 4.3)$ and the reaction was run at $37^{\circ} \mathrm{C}$ for $16 \mathrm{~h}$. Bacillus stearothermophilus $\alpha$ glucosidase $(0.5 \mathrm{mg} / \mathrm{ml})$ digestion was done in $0.2 \mathrm{M}$ sodium acetate buffer $\left(\mathrm{pH} \mathrm{5)}\right.$ at $37^{\circ} \mathrm{C}$ for $16 \mathrm{~h}$. Clostridium perfringens type $\mathrm{V}$ neuraminidase $(5 \mathrm{U} / \mathrm{ml})$ treatment of cells was done at $37^{\circ} \mathrm{C}$ for $16 \mathrm{~h}$ in $50 \mathrm{mM}$ sodium acetate buffer (pH 5.5) containing $4 \mathrm{mM} \mathrm{CaCl}_{2}$, and BSA $0.1 \mathrm{mg}$. Flavobacterium heparinum heparinase $1(0.1 \mathrm{U} / \mathrm{ml})$, Proteus vulgaris chondroitinase $\mathrm{ABC}(0.1 \mathrm{U} / \mathrm{ml})$ and bovine testes hyaluronidase type Vl-S $(1 \mathrm{U} / \mathrm{ml})$ digestion were done at $37^{\circ} \mathrm{C}$ for $24 \mathrm{~h}$ in $0.05 \mathrm{M}$ sodium acetate buffer (pH 5.8) containing BSA $0.2 \mathrm{mg} / \mathrm{ml}$. After each treatment, the monolayers were washed three times with PBS and blocked with BSA $3 \%$ for $1 \mathrm{~h}$ at $37^{\circ} \mathrm{C}$. After washing with PBS-Tween, plates were used for the enzyme-linked, biotin-steptavidin bacterial adhesion assay as described above. 


\section{Detachment}

To measure detachment, H. pylori was first allowed to bind to HeLa S3 and Kato III semi-confluent monolayers for $90 \mathrm{~min}$ at $37^{\circ} \mathrm{C}$ as described above. After washing the 96-well tissue-culture plates with PBS-Tween to remove non-adhering bacteria, rabbit polyclonal antibodies against the $71.5-\mathrm{kDa}$ HSBP and non-immune rabbit serum were added to the 96-well tissue-culture plates in $100 \mu \mathrm{l}$ of PBS at different concentrations. Plates were washed with PBS-Tween after incubation for $60 \mathrm{~min}$ at $22^{\circ} \mathrm{C}$, and residual bacteria were quantified as described above.

\section{Antisera}

To raise antisera against the $71.5-\mathrm{kDa}$ extracellular $H$. pylori HSBP [26], c. $30 \mu \mathrm{g}$ of HSBP protein band was isolated from a SDS-PAGE preparation, emulsified with Freund's adjuvant and injected intramuscularly in rabbits three times at intervals of 2 weeks. Antiserum was collected 2 weeks after the final antigen dose. Immunoblotting and ELISA assays were performed to ensure that the antiserum contained antibodies that recognised the $71.5-\mathrm{kDa}$ extracellular $H$. pylori HSBP (data not shown).

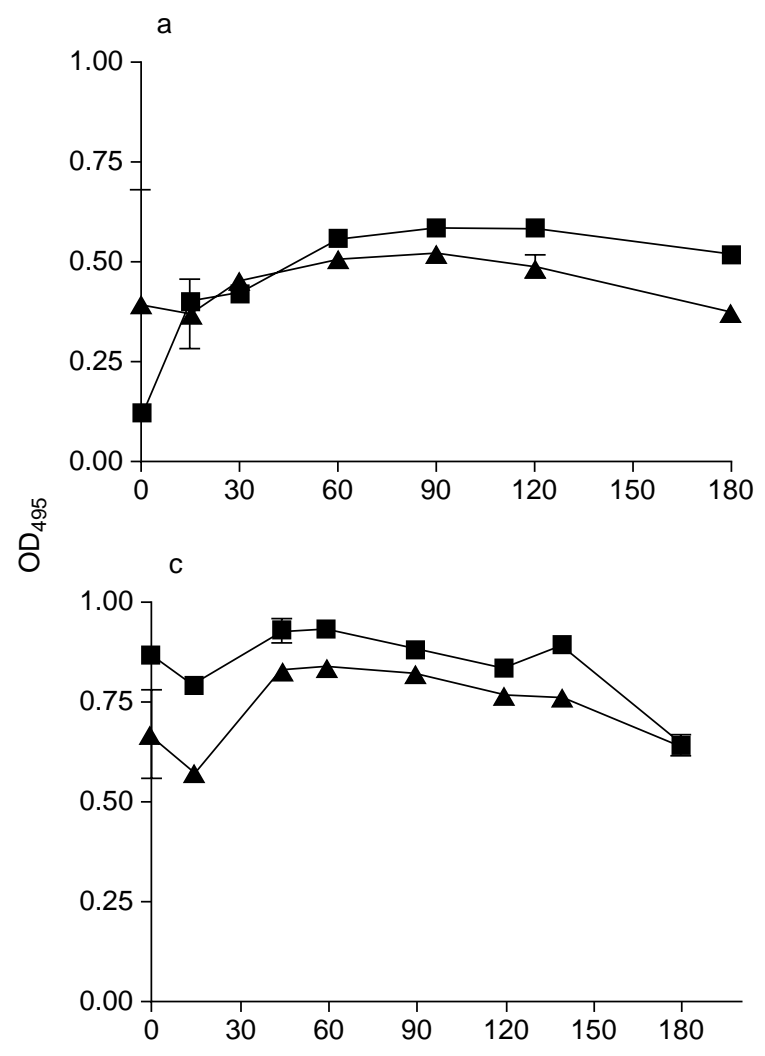

\section{Statistical analysis}

Student's $t$ test was used to assess the significance of differences between means in binding and inhibition assays. Comparisons involving more than two groups were performed with ANOVA. Values are expressed as means (SD) of at least three experiments.

\section{Results}

Effect of repetitive passsage of $H$. pylori through the BALB/c intestinal tract on adherence to HeLa S3 and Kato III cell lines

Because of interest in the development of HSBP-based vaccines against $H$. pylori infections, and the possibility of using the BALB/c mouse to study $H$. pylori adhesion and colonisation factors in vivo, this study aimed to evaluate whether repetitive passage of $H$. pylori through the BALB/c gut enhanced its ability to adhere to both live semi-confluent monolayers (Fig. 1a and b) and formaldehyde-fixed cell monolayers (Fig. 1c and d) of HeLa S3 and Kato III cells. Both the $H$. pylori wild strain (Fig. 1a and c) and the corresponding mouse-adapted strain (Fig. $1 \mathrm{~b}$ and $\mathrm{d}$ ) adhered to HeLa S3 and Kato III cells in a similar manner. The doseresponse adherence of $H$. pylori 25 and its correspond-
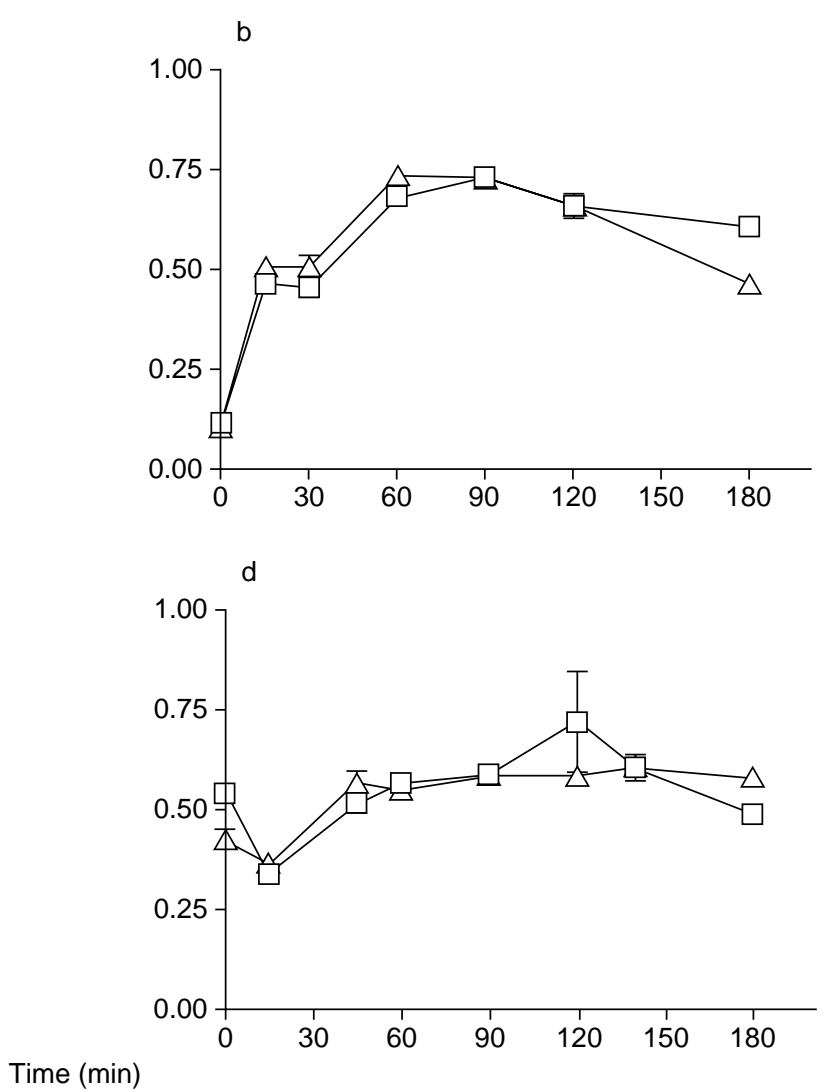

Fig. 1. Effect of repetitive passage of $H$. pylori through the BALB/c mouse intestinal tract on its adherence to HeLa S3 $(\boldsymbol{\square}, \square)$ and Kato III $(\boldsymbol{\Delta}, \triangle)$ cell lines. (a) and (c) show the adhesion of H. pylori strain $25(\boldsymbol{\square}, \boldsymbol{\Delta})$ to live and formaldehyde-fixed cells, respectively. (b) and (d) show the adhesion of the mouse-adapted H. pylori strain 25 ( $\square, \triangle$ ) to live and formaldehyde-fixed cells, respectively. Each point represents the mean of three experiments; bars indicate SD. 
ing mouse-adapted strain to HeLa S3 and Kato III cells were determined. $H$. pylori strain 25 showed a tendency to adhere more to Kato III cells (Fig. 2a), whereas the mouse-adapted $H$. pylori strain adhered more to HeLa S3 cells (Fig. 2b). In both cases, there was a dose-dependent effect on bacterial adhesion to HeLa S3 and Kato III cell lines.

\section{Evidence of the HSBPs from $H$. pylori} participating in adherence to HeLa S3 and Kato III cells

A series of studies was conducted to determine whether the HSBPs are important for the adhesion of $H$. pylori to HeLa S3 and Kato III cells. Because the HSBP is an extracellular lectin, the study aimed to determine whether its presence in the medium surrounding $H$. pylori could be an element for cell adhesion. First, the question as to whether soluble HSBP can be bound to H. pylori cells was addressed. H. pylori strain 25 and its corresponding mouse-adapted variant were incubated with increasing concentrations of horseradish peroxidase labelled HSBP. Fig. 3 shows the doseresponse binding kinetics of horseradish peroxidase labelled HSBP to H. pylori cells.

The next step was to determine whether soluble HSBP could promote adhesion of $H$. pylori to HeLa S3 and Kato III cells. Bacterial cells were incubated with soluble HSBP before the adhesion assay. HSBP enhanced the adhesion of $H$. pylori strain 25 (Fig. 4a) and its corresponding mouse-adapted variant (Fig. 4b) to HeLa S3 and Kato III cells.

A similar assay was performed with glycosidase-treated HeLa S3 and Kato III cells (Table 1). Treatment of HeLa S3 cells with neuraminidase, chondroitinase, keratanase and galactosidase before the adherence assay significantly reduced $(p \leqslant 0.005)$ adherence of H. pylori strain 25 (Table 1). However, when the same

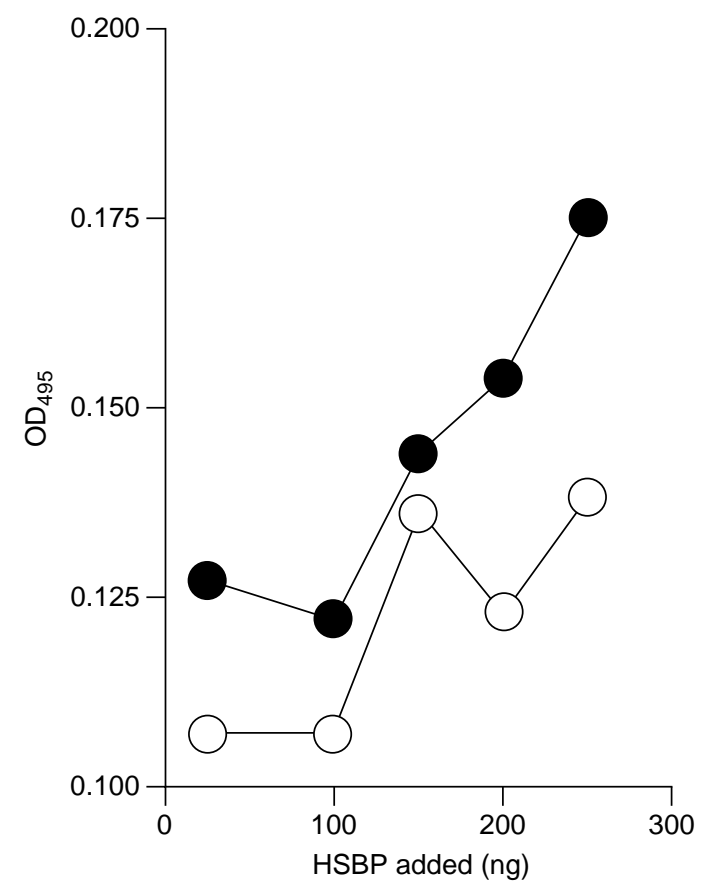

Fig. 3. Binding of horseradish peroxidase-labelled HSBP to $H$. pylori strain $25(\mathbf{O})$ and its corresponding mouseadapted variant $(O)$. Different concentrations of horseradish peroxidase-labelled HSBP were incubated with the H. pylori cells and adherence was assessed by the same procedure as used to evaluate the adherence of bacteria to cultured cells outlined in Materials and methods. Each point represents the mean of three experiments.

glycosidase treatment was done in the presence of extracellular HSBP, a distinct pattern was observed; there was no promotion but rather inhibition of $H$. pylori adherence to HeLa S3 cells (Table 1). An analogous pattern was observed in the adhesion of $H$. pylori to glycosidase-treated Kato III cells (Table 1). Pre-treatment of Kato III cells with neuraminidase and glucosidase resulted in a reduction of $H$. pylori adherence (Table 1). Futhermore, adhesion of H. pylori

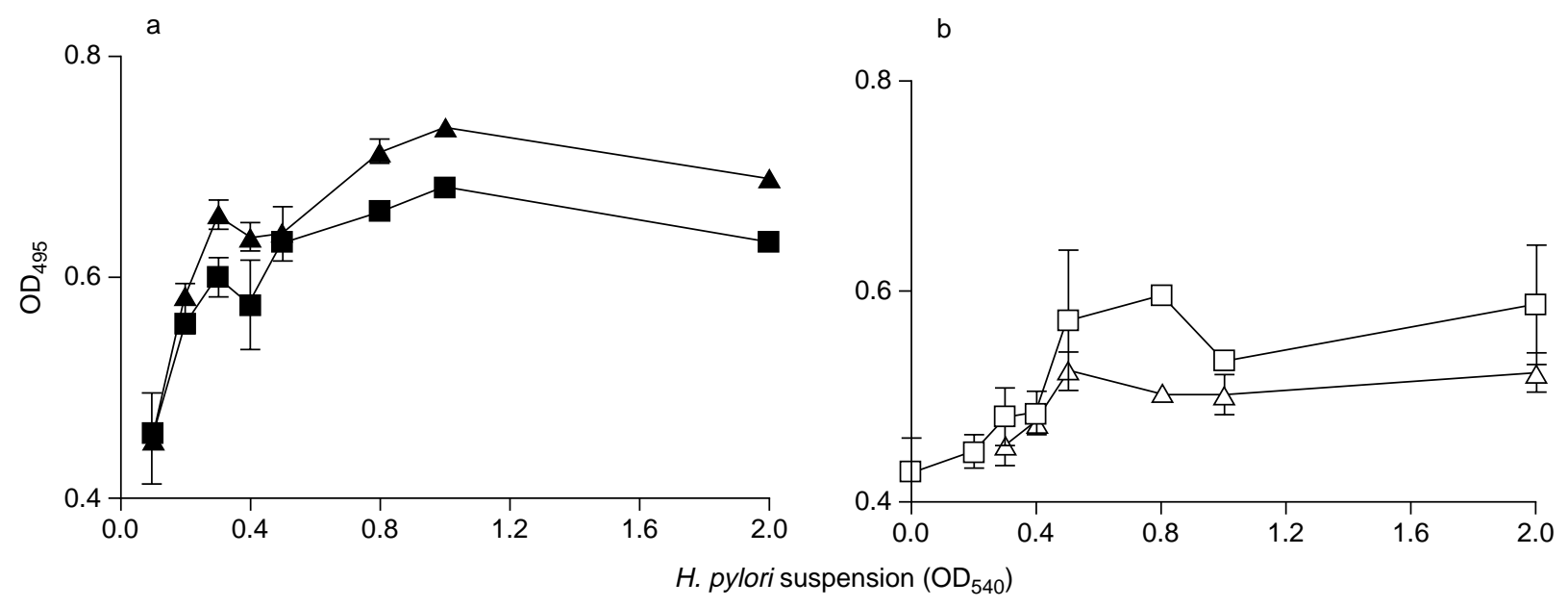

Fig. 2. Dose-course kinetics of $H$. pylori strain 25 (a) and its corresponding mouse-adapted variant (b) adhesion to HeLa S3 $(\boldsymbol{\square}, \square)$ and Kato III $(\boldsymbol{\Delta}, \triangle)$ cell monolayers. Bacteria input, $\mathrm{OD}_{540}$ of $1.0,1 \times 10^{8} \mathrm{cfu} / \mathrm{ml}$. Each point represents the mean of three experiments; bars indicate SD. 


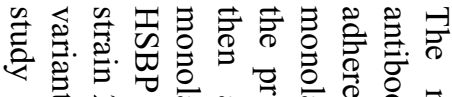

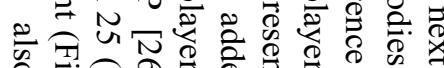
० प्र

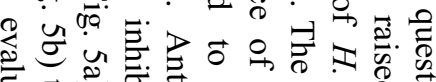

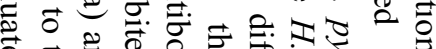

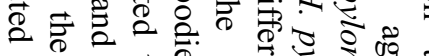

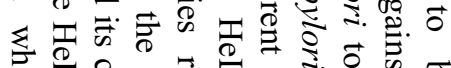
ब

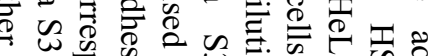

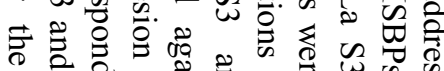

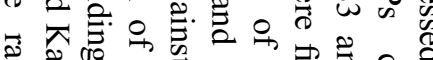
б

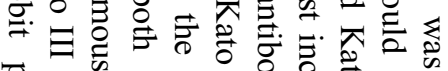

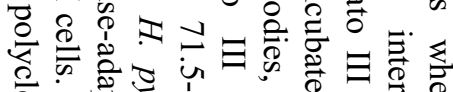

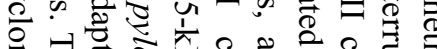

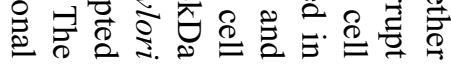

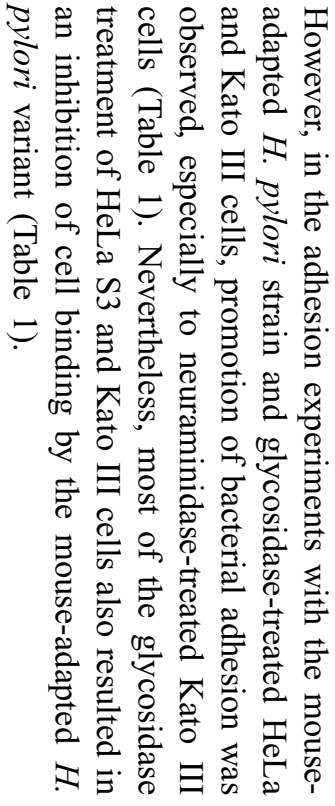

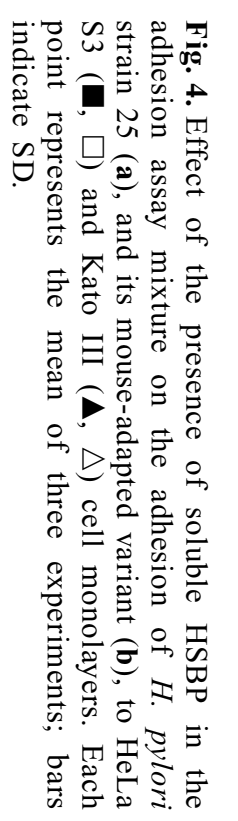

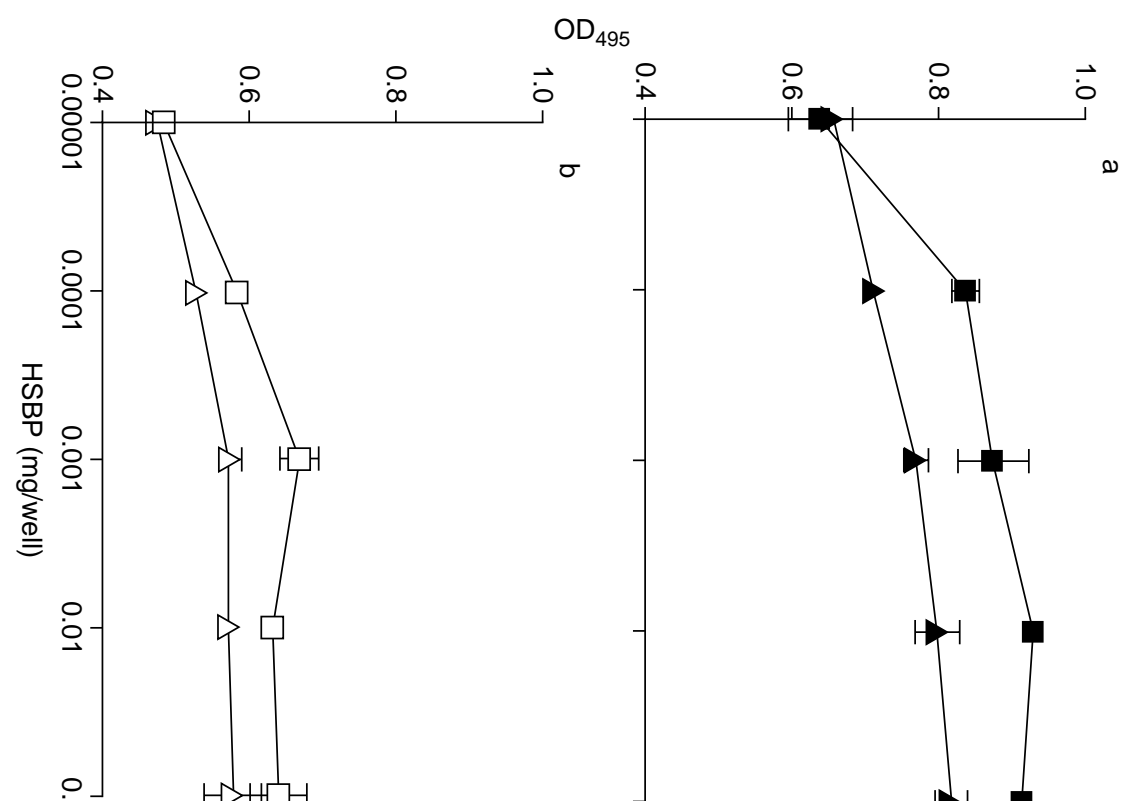

Table 1. Adhesion of H. pylori strain 25 and its corresponding mouse-adapted variant to glycosidase-treaated HeLa S3 and Kato III cell monolayers in presence or absence of soluble HSBP

\begin{tabular}{|c|c|c|c|c|c|c|c|c|}
\hline \multirow[b]{2}{*}{ H. pylori strain and cell monolayer presentation } & \multicolumn{8}{|c|}{ Adhesion of $H$. pylori measured as $\mathrm{OD}_{495}$ (SD) to cell monolayers treated with } \\
\hline & No treatment & Keratanase & Galatosidase & Glucosidase & Neuraminidase & Heparitinase & Chondroitinase & Hyaluronidase \\
\hline \multicolumn{9}{|l|}{ H. pylori strain 25} \\
\hline Glycosidase-treated HeLa & $0.603(0.030)$ & $0.533(0.016)$ & $0.539(0.020)$ & $0.533(0.015)$ & $0.512(0.007)$ & $0.561(0.007)$ & $0.523(0.015)$ & $0.567(0.011)$ \\
\hline Glycosidase-treated HeLa + HSBP & $0.556(0.032)$ & $0.437(0.044)$ & $0.479(0.012)$ & $0.524(0.024)$ & $0.497(0.007)$ & $0.513(0.015)$ & $0.458(0.007)$ & $0.523(0.012)$ \\
\hline Glycosidase-treated Kato & $0.686(0.028)$ & $0.696(0.037)$ & $0.886(0.030)$ & $0.634(0.026)$ & $0.589(0.009)$ & $0.639(0.012)$ & $0.636(0.035)$ & $0.672(0.018)$ \\
\hline Glycosidase-treated Kato + HSBP & $0.640(0.027)$ & $0.554(0.032)$ & $0.574(0.006)$ & $0.573(0.003)$ & $0.571(0.004)$ & $0.532(0.043)$ & $0.555(0.023)$ & $0.602(0.03)$ \\
\hline \multicolumn{9}{|l|}{ Mouse-adapted $H$. pylori } \\
\hline Glycosidase-treated HeLa & $0.458(0.009)$ & $0.441(0.043)$ & $0.422(0.010)$ & $0.456(0.031)$ & $0.485(0.050)$ & $0.434(0.006)$ & $0.399(0.004)$ & $0.433(0.012)$ \\
\hline Glycosidase-treated HeLa + HSBP & $0.482(0.050)$ & $0.363(0.013)$ & $0.414(0.058)$ & $0.478(0.067)$ & $0.473(0.015)$ & $0.406(0.039)$ & $0.379(0.027)$ & $0.386(0.015)$ \\
\hline Glycosidase-treated Kato & $0.598(0.002)$ & $0.501(0.015)$ & $0.508(0.015)$ & $0.481(0.011)$ & $0.556(0.021)$ & $0.474(0.018)$ & $0.481(0.014)$ & $0.514(0.06)$ \\
\hline Glycosidase-treated Kato + HSBP & $0.468(0.005)$ & $0.406(0.023)$ & $0.445(0.015)$ & $0.426(0.011)$ & $0.534(0.017)$ & $0.416(0.014)$ & $0.429(0.007)$ & $0.427(0.009)$ \\
\hline
\end{tabular}




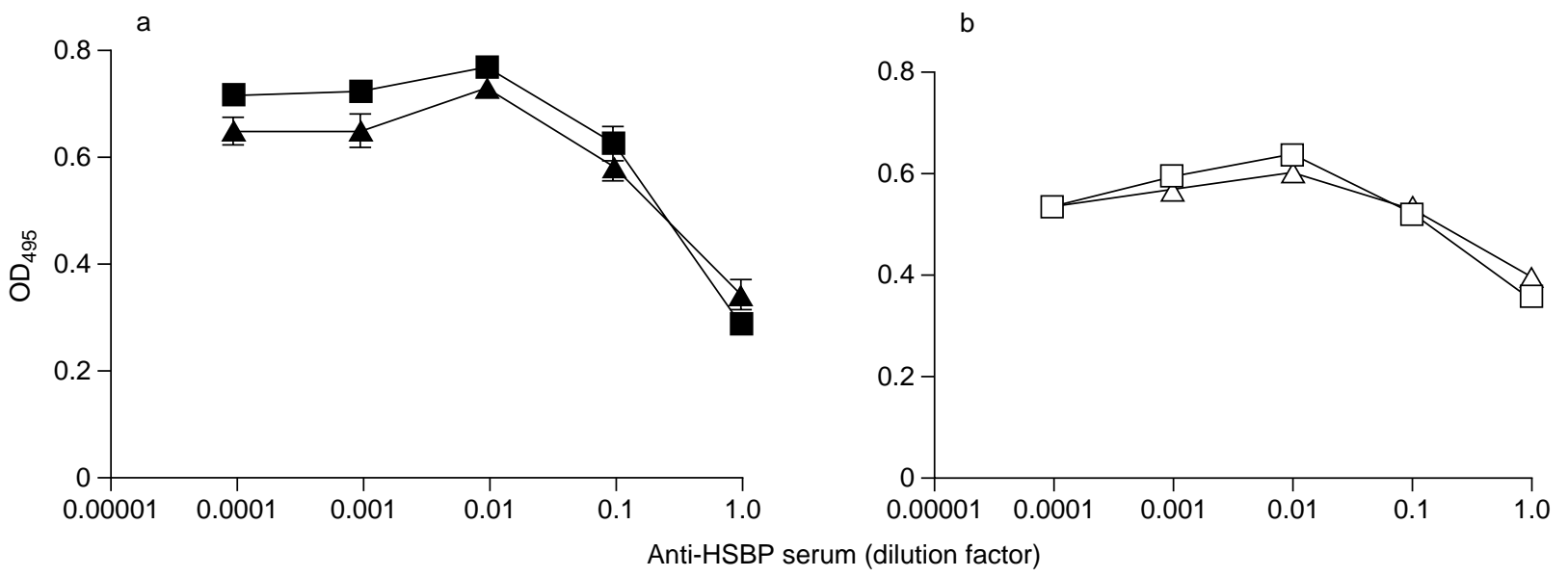

Fig. 5. Blocking of $H$. pylori adherence with anti-HSBP. Rabbit antiserum against a $71.5-\mathrm{kDa}$ HSBP from $H$. pylori was used to block adherence of $H$. pylori strain 25 (a), and its corresponding mouse-adapted variant (b), to HeLa S3 $(\boldsymbol{\square}, \square)$ and to Kato III cell monolayers $(\boldsymbol{\Delta}, \triangle)$. Each point represents the mean of three experiments; bars indicate SD.

Table 2. Blocking of adhesion of $H$. pylori strains to HeLa S3 and Kato III cell monolayers after pre-incubation of bacterial cells with rabbit anti-serum (diluted 1 in $10 \mathrm{v} / \mathrm{v}$ ) against a $71.5-\mathrm{kDa}$ HSBP

\begin{tabular}{lcc}
\hline & \multicolumn{2}{c}{$\begin{array}{c}\text { Percentage blocking of adherence } \\
\text { of } H . \text { pylori to }\end{array}$} \\
\cline { 2 - 3 } H. pylori strain & Kato III cells & HeLa S3 cells \\
\hline GERD-associated strains & & \\
20 & 80 & 80 \\
72 & 65 & 54 \\
91 & 70 & 51 \\
125 & 82 & 71 \\
152 & 59 & 55 \\
185 & 37 & 41 \\
193 & 63 & 61 \\
238 & 62 & 59 \\
291 & 80 & 70 \\
Gastric cancer-associated strain & & 48 \\
1117 & 72 & 49 \\
Duodenal ulcer-associated strains & & 68 \\
1126 & 72 & 77 \\
RH-54 & 50 & 59 \\
Reference strains & & \\
51110 (ure- mutant from ATCC 49503) & 67 & \\
ATCC 51932 & 48 & \\
\hline
\end{tabular}

antibodies raised against the 71.5-kDa HSBP could block the adhesion of different $H$. pylori strains to HeLa S3 and Kato III cell monolayers. Table 2 shows that the anti-HSBP blocked the adherence of $H$. pylori to differing extents depending on the strain. There was no inhibition in similar studies with non-immune rabbit serum (data not shown).

A separate experiment aimed to determine whether the antibodies raised against the $71.5-\mathrm{kDa} \mathrm{HSBP}$ could detach $H$. pylori bound to HeLa S3 and Kato III cells. Fig. $6 \mathrm{a}$ and $6 \mathrm{~b}$ shows that there was some $H$. pylori detachment; however, it was not as great as the results for inhibition of adherence. Rabbit non-immune sera did not displace cell-bound $H$. pylori strain 25 or its corresponding mouse-adapted variant (data not shown).

\section{Discussion}

Many studies of $H$. pylori adhesion in vitro have shown binding of the bacteria to various cell lines in tissue culture, including primary cultures of human gastric epithelial cells $[7,9,10,16]$. However, the mechanisms by which $H$. pylori adheres to various human gastric carcinoma cells with differing affinity are not fully clear. It is possible that the affinity of $H$. pylori for gastric carcinoma cells in terms of adhesion might be due to different surface structures based upon tumour characteristics [28]. Recent studies indicate that $H$. pylori adherence to cultured gastric epithelial cells is associated with several cellular events, including reorganisation of the host cell's actin, tyrosine phosphorylation of a $145-\mathrm{kDa}$ protein and cytokine release [29]. 


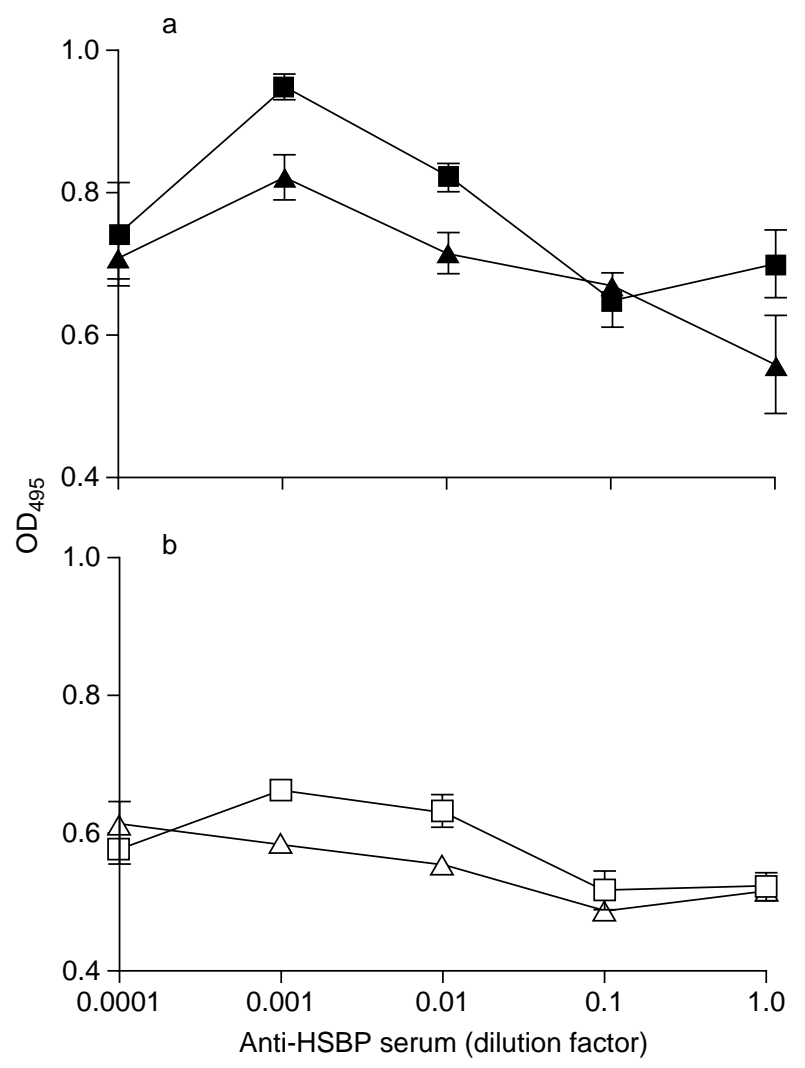

Fig. 6. Partial detachment of bound bacteria by rabbit antiserum against a $71.5-\mathrm{kDa}$ HSBP from $H$. pylori strain 25 (a) and the mouse-adapted H. pylori variant (b) were incubated with $\mathrm{HeLa}$ S3 $(\boldsymbol{\square}, \square)$ and Kato III $(\boldsymbol{\Delta}$, $\triangle$ ) cell monolayers for $1 \mathrm{~h}$, and unbound bacteria were removed by three washes with PBS-Tween 20, and further incubated for $1 \mathrm{~h}$ with the indicated serum dilutions. Each point represents the mean of three experiments; bars indicate SD.

Osaki et al. [28] suggested the possibility that haemagglutinins and other surface components may be co-operatively involved in adhesion of $H$. pylori to cultured cells. It has also been reported that Lewis ${ }^{b}$ antigen and other fucosylated blood group antigens function as receptors for $H$. pylori attachment to fixed gastric tissue [30]; however, binding to Kato III cells is independent of Lewis ${ }^{\mathrm{b}}$ antigen [15,31]. Previous studies in this laboratory showed that the ability of $H$. pylori to bind heparan sulphate was not correlated with haemagglutination activity (unpublished data). $H$. pylori urease has been shown to bind gastric mucin, heparin and related heparinoids [32]. However, urease does not play a role in the adherence of $H$. pylori to gastric cells [33]. A $20-\mathrm{kDa}$ haemagglutinin with affinity for $\mathrm{N}$-acetylneuraminyl-lactose in mammalian cells in culture has been identified as a putative colonisation factor for H. pylori [34]. Fauchere and Blaser [35] described a $15-\mathrm{kDa}$ antigen in $H$. pylori bacterial extracts that adhered to both neuraminidasetreated and native HeLa cells.

Namavar et al. [36] identified a 16-kDa OMP from $H$. pylori with affinity for sulphated carbohydrates of mucin and for Lewis $\mathrm{x}$ blood group antigen. Odenbreit et al. [37] identified a novel genetic locus, the alp $A B$ operon, which encodes two closely homologous integral outer-membrane proteins (OMPs) directly involved in adhesion of $H$. pylori to Kato III cells and to human gastric tissues. They also found that the pattern of AlpAB-dependent adherence of $H$. pylori to gastric epithelial surfaces showed a clear difference from the BabA2-mediated adherence to Lewis ${ }^{\mathrm{b}}$ antigen, suggesting that a different receptor is involved.

It has been demonstrated that $H$. pylori binds to heparan sulphate and to heparin-dependent acidic and basic fibroblast growth factors [14,21]. Utt and Wadström [38] found that $H$. pylori expressed a number of OMPs with affinity for heparin, and the authors of the present study recently found that besides a 45-kDa OMP HSBP, H. pylori produces three major extracellular HSBPs, one with a mol. wt of $66.2 \mathrm{kDa}$ and a $\mathrm{pI}$ of 5.4 , and another with a mol. wt of $71.5 \mathrm{kDa}$ and a pI of 5.0 [26].

Two series of experiments serve to highlight the importance of the extracellular HSBPs for adhesion of $H$. pylori to Kato III and HeLa cells. First, studies of adhesion of $H$. pylori to cultured cells in the presence of extracellular HSBP showed enhancement of bacterial attachment to both Kato III and HeLa cells. Second, binding inhibition studies with rabbit polyclonal antibodies against the extracellular $71.5-\mathrm{kDa}$ HSBP of $H$. pylori, but not with non-immune rabbit serum, resulted in blockade of adhesion of $H$. pylori to cultured cells and detachment of cell-bound H. pylori from both HeLa and Kato III cell lines. These findings are important, as monoclonal antibodies to $\mathrm{Le}^{\mathrm{a}}$ and $\mathrm{Le}^{\mathrm{b}}$ did not inhibit adherence of $H$. pylori to Kato III cells [31] and because the in-vitro demonstration that antiHSBP can prevent adherence as well as induce detachment of cell-bound H. pylori, suggests that an HSBP-based vaccine preparation may be of value for protection against and eradication of $H$. pylori infections, as has been suggested recently [22]. It may be true that bacterial adherence is comprised of multiple non-covalent contact points, each in dynamic equilibrium. In principle, therefore, molecules capable of competitively inhibiting adhesion-ligand interaction will not only prevent binding, but also disrupt established adherence [16].

Treatment of cultured cells with glycosidases and endoglycolytic enzymes altered the binding of $H$. pylori strain 25 and its corresponding mouse-adapted variant to both HeLa S3 and Kato III cell lines (Table 1). Extracellular HSBP did not promote adhesion of mouse-adapted $H$. pylori to glycosidase-treated cultured cells, except in binding to neuraminidase-treated Kato III, where there was an enhancement of bacterial adhesion, and to glucosidase- and neuraminidasetreated HeLa S3 cells, where a tendency to promote bacterial adherence was observed. As reported by 
Simon et al. [16], glycosidase treatment of Kato III cells resulted in altered bacterial binding but, most importantly, enzymic digestion with glycosidases suggsets that H. pylori adhesion to gastric epithelial cells may rely on more than one adhesin.

Based on the report of Simon et al. [16] that the sensitivity of $H$. pylori to $3^{\prime}$ sialyl-lactose (NeuAc $\alpha 2-$ $3 \mathrm{Gal} / 31-4 \mathrm{Glc}$; 3'SL) inhibition of binding to gastrointestinal epithelial cells diminished with increasing passage number, the present study evaluated whether the HSBP has any effect on the adhesion of a recently mouse-adapted $H$. pylori strain. Both $H$. pylori strain 25 and its corresponding mouse-adapted variant showed similar adhesion patterns to HeLa S3 and Kato III cell lines, which suggests that the adhesion activity of $H$. pylori strain 25 to both HeLa S3 and Kato III cell lines is not altered by serial passage.

Duensing et al. [39] proposed a novel strategic mimicry pathogenicity model based on heparan sulphate glycosaminoglycan-directed recruitment of mammalian host proteins to compromise the host's immune system. According to this model, bacterial pathogens need direct cell contact with a host-soluble glycosaminoglycan. The glycosaminoglycans bound at the bacterial cell surface subsequently serve as universal binding sites for any mammalian heparin-binding protein, without producing separate receptors for each protein. The repertoire of surface-bound proteins may affect various aspects of microbial virulence and host defence systems, such as chemotaxis, tissue invasion, tissue integrity and immunological responses [39].

However, if the fact that heparan sulphate glycosaminoglycan is exposed only during wound healing [40, 41] is taken into consideration, it would be an advantage for the bacteria to coat itself with the heparan sulphate glycosaminoglycan. A possible mechanism to achieve this would be the production of competitive extracellular HSBP. Producing an extracellular HSBP would enable the pathogen to search for soluble heparan sulphate glycosaminoglycan and then bring it to the bacterial cell for further recruitment of mammalian host heparin-binding proteins such as chemokines, growth factors, extracellular matrix proteins, enzymes and cytokines. Furthermore, because heparan sulphates are common constituents of the cell surface and the extracellular matrix [42], especially exposed during wound healing, they may serve as additional receptors for bacterial attachment. It has recently been reported by Hirmo et al. [43] that heparin and other sulphated oligosaccharides can block the binding of $H$. pylori to immobilised sulphated mucins. The HSBPs from $H$. pylori may be involved in different biological processes, and not only in the adhesion of the bacteria to sulphated proteoglycans, as is the case for heparan sulphate, heparin, or heparin-dependent fibroblast growth factors. Thus it is possible that HSBPs may also be involved in the adhesion of the bacteria to sulphomucins [13] and to sulphated glycolipids [12] exposed on the human gastric mucosal cells.

This work was supported by a grant from the Center for Biological Research (ABM-11) to F.A, M.A.G.M. and E.R.B. were recipients of a graduate scholarship from the Mexican Council of Science and Technology (CONACYT). We thank Dr Tania Zenteno-Savn for her comments and for editing the English language text.

\section{References}

1. Forman D, Newell DG, Fullerton F et al. Association between infection with Helicobacter pylori and risk of gastric cancer: evidence from a prospective investigation. BMJ 1991; 302: $1302-1305$.

2. Moss S, Calam J. Helicobacter pylori and peptic ulcers; the present position. Gut 1992; 33: 289-292.

3. Wotherspoon AC, Ortiz-Hidalgo C, Falzon MR, Isaacson PG. Helicobacter pylori-associated gastric and primary B-cell gastric lymphoma. Lancet 1991; 338: 1175-1176.

4. Evans DG, Evans DJ. Adhesion properties of Helicobacter pylori. Methods Enzymol 1995; 253: 336-360.

5. Trust TJ, Doig P, Emödy L, Kienle Z, Wadström T, O' Toole P. High-affinity binding of the basement membrane proteins collagen type IV and laminin to the gastric pathogen Helicobacter pylori. Infect Immun 1991; 59: 4398-4404.

6. Simon-Assman P, Kedinger M, Haffen K. Immunocytochemical localization of extracellular-matrix proteins in relation to rat intestinal morphogenesis. Differentiation 1986; 32: 59-66.

7. Clyne M, Drumm B. Adherence of Helicobacter pylori to primary human gastrointestinal cells. Infect Immun 1993; 61: $4051-4057$.

8. Lingwood CA, Wasfy G, Han H, Huesca M. Receptor affinity purification of a lipid-binding adhesin from Helicobacter pylori. Infect Immun 1993; 61: 2474-2478.

9. Wadström T, Ascencio F, Ljungh $\AA$ et al. Helicobacter pylori adhesins. Eur J Gastroenterol Hepatol 1993; 5 Suppl 2: S12S15.

10. Wadström T, Hirmo S, Borén S. Biochemical aspects of Helicobacter pylori colonization of the human gastric mucosa. Aliment Pharmacol Ther 1996; 10 suppl 1: 17-27.

11. Evans DG, Evans DJ, Graham DY. Adherence and internalization of Helicobacter pylori by Hep-2 cells. Gastroenterology 1992; 102: 1557-1567.

12. Saitoh $\mathrm{T}$, Natomi $\mathrm{H}$, Zhao $\mathrm{W}$ et al. Identification of glycolipid receptor for Helicobacter pylori by TLC-immunostaining. FEBS Lett 1991; 282: 385-387.

13. Slomiany BL, Piotrowski J, Slomiany A. Effect of sucralfate on the degradation of human gastric mucus by Helicobacter pylori protease and lipases. Am J Gastroenterol 1992; 87: 595-599.

14. Ascencio F, Fransson L- $\AA$, Wadström T. Affinity of the gastric pathogen Helicobacter pylori for the N-sulphated glycosaminoglycan heparan sulphate. J Med Microbiol 1993; 38: 240-244.

15. Kamisago $\mathrm{S}$, Iwamori $\mathrm{M}$, Tai $\mathrm{T}$, Mitamura $\mathrm{K}$, Yazaki $\mathrm{Y}$, Sugano K. Role of sulfatides in adhesion of Helicobacter pylori to gastric cancer cells. Infect Immun 1996; 64: 624-628.

16. Simon PM, Goode PL, Mobasseri A, Zopf D. Inhibition of Helicobacter pylori binding to gastrointestinal epithelial cells by sialic acid-containing oligosaccharides. Infect Immun 1997; 65: $750-757$

17. Borén T, Falk P, Roth KA, Larson G, Normark S. Attachment of Helicobacter pylori to human gastric epithelium mediated by blood group antigens. Science 1993; 262: 1892-1895.

18. Valkonen KH, Ringner M, Ljungh A, Wadström T. Highaffinity binding of laminin by Helicobacter pylori: evidence for a lectin-like interaction. FEMS Immunol Med Microbiol 1993; 7: 29-37.

19. Chmiela M, Paziak-Domanska B, Rudnicka W, Wadström T. The role of heparan sulphate-binding activity of Helicobacter pylori bacteria in their adhesion to murine macrophages. APMIS 1995; 103: 469-474.

20. Kung JSL, Ho B, Chan SH. Biotyping of Campylobacter pylori. J Med Microbiol 1989; 29: 203-206.

21. Ascensio F, Hansson HA, Larm O, Wadström T. Helicobacter pylori interacts with heparin and heparin-dependent growth factors. FEMS Immunol Med Microbiol 1995; 12: 265-272. 
22. Ruiz-Bustos E, Sierra-Beltran A, Romero MJ, RodriguezJaramillo C, Ascencio F. Protection of BALB/c mice against experimental Helicobacter pylori infection by oral immunisation with $H$. pylori heparan sulphate-binding proteins coupled to cholera toxin $\beta$-subunit. J Med Microbiol 2000; 49: 535541 .

23. Soltesz V, Schalen C, Mardh P-A. New selective medium for Campylobacter pylori. In: Proceedings of the Fourth International Workshop on Campylobacter infection. Kaijser B, Falsen E (eds) Gothenbörg, Sweden, 1988: 433-436.

24. Harlow E, Lane DP. Antibodies. A laboratory manual. Cold Spring Harbor, NY, Cold Spring Harbor Laboratory. 1988: 319-358.

25. Marchetti M, Aricó B, Burroni D, Figura N, Rappuoli R, Ghiara P. Development of a mouse model of Helicobacter pylori infection that mimics human diseases. Science 1995; 267: $1655-1658$.

26. Ruiz-Bustos E, Ochoa JL, Wadström T, Ascencio F. Isolation and characterization of putative adhesins from Helicobacter pylori with affinity for heparan sulphate proteoglycan. $J$ Med Microbiol (in press).

27. Amini H-R, Ascencio F, Ruiz-Bustos E, Romero MJ, Wadström T. Cryptic domains of a $60-\mathrm{kDa}$ heat shock protein of Helicobacter pylori bound to bovine lactoferrin. FEMS Immunol Med Microbiol 1996; 16: 247-255.

28. Osaki T, Yamaguchi H, Taguchi H, Kumada J, Ogata S, Kamiya S. Studies on the relationship between adhesive activity and haemagglutination by Helicobacter pylori. J Med Microbiol 1997; 46: 117-121.

29. Segal ED, Lange C, Covacci C, Tompkins LS, Falkow S. Induction of host signal transduction pathways by Helicobacter pylori. Proc Natl Acad Sci USA 1997; 94: 7595-7599.

30. Su B, Hellström PM, Rubio C, Çelik J, Granström M, Normark $\mathrm{S}$. Type I Helicobacter pylori shows Lewis $^{\mathrm{b}}$-independent adherence to gastric cells requiring de novo protein synthesis in both host and bacteria. J Infect Dis 1998; 178: 1379-1390.

31. Clyne M, Drumm B. Absence of effect of Lewis A and Lewis B expression on adherence of Helicobacter pylori to human gastric cells. Gastroenterology 1997; 113: 72-80.

32. Icatlo FC, Kuroki M, Kobayashi C et al. Affinity purification of Helicobacter pylori urease. Relevance to gastric mucin adher- ence by urease protein. J Biol Chem 1998; 273: 18130-18138

33. Clyne M, Drumm B. The urease enzyme of Helicobacter pylori does not function as an adhesin. Infect Immun 1996; 64: 2817-2820.

34. Evans DG, Evans DJ, Moulds JJ, Graham DY. N-acetylneuraminyllactose-binding fibrillar hemagglutinin of Campylobacter pylori: a putative colonization factor antigen. Infect Immun 1998; 56: 2896-2906.

35. Fauchere J-L, Blaser MJ. Adherence of Helicobacter pylori cells and their surface components to HeLa cell membranes. Microb Pathog 1990; 9: 427-439.

36. Namavar F, Sparrius M, Veerman ECI, Appelmelk BJ, Vandenbroucke-Grauls CMJE. Neutrophil-activating protein mediates adhesion of Helicobacter pylori to sulfated carbohydrates on high-molecular-weight salivary mucin. Infect Immun 1998; 66: 444-447.

37. Odenbreit S, Till M, Hofreuter D, Faller G, Haas R. Genetic and functional characterization of the alpAB gene locus essential for the adhesion of Helicobacter pylori to human gastric tissue. Mol Microbiol 1999; 31: 1537-1548.

38. Utt M, Wadström T. Identification of heparan sulphate binding surface proteins of Helicobacter pylori: inhibition of heparan sulphate binding with sulphated carbohydrate polymers. $J$ Med Microbiol 1997; 46: 541-546.

39. Duensing TD, Wing JS, van Putten JPM. Sulfated polysaccharide-directed recruitment of mammalian host proteins: a novel strategy in microbial pathogenesis. Infect Immun 1999; 67: 4463-4468

40. Andriessen MP, van den Born J, Latijnhouwers MA, Bergers M, van de Kerkof PC, Schalkwijk J. Basal membrane heparan sulphate proteoglycan expression during wound healing in human skin. J Pathol 1997; 183: 264-271.

41. Okasala O, Salo T, Tammin R et al. Expression of proteoglycans and hyaluronan during wound healing. $J$ Histochem Cytochem 1995; 43: 125-135.

42. Stringer SE, Gallagher JT. Heparan sulphate. Int J Biochem Cell Biol 1997; 29: 709-714.

43. Hirmo S, Artursson E, Puu G, Wadström T, Nilsson B. Helicobacter pylori interactions with human gastric mucin studied with a resonant mirror biosensor. J Microbiol Methods 1999; 37: 177-182. 